\title{
Asymmetric Decentralization and Peace Building: A Comparison of Aceh and Northern Ireland
}

\author{
Ali Abdurahman, ${ }^{*}$ Bilal Dewansyah ${ }^{* *}$ \\ DOI: https://doi.org/10.22304/pjih.v6n2.a3 \\ Submitted: April 15, 2019 | Accepted: April 16, 2019
}

\begin{abstract}
This article compares the asymmetric form of decentralization model in the Aceh, Indonesia, and in the Northern Ireland, the United Kingdom, towards the process of peacemaking. In general, the decentralization models in the two regions have almost similar backgrounds due to prolonged religious conflicts. However, the devolution model in Northern Ireland is far more complex than Aceh's, and closely related to other countries, that affect the constitutional status of Northern Ireland in the future. This is different from the Aceh government, which since the Helsinki MoU has remained a part of the Indonesia's unitary form. On the other hand, in terms of governmental matters, decentralization in Aceh reflects a reduction in their special authority, with a pattern of division of government functions that is almost similar to the division of functions in the ordinary regional government. It is in contrast to the affairs of Northern Ireland's government concerning matters that are categorized traditionally as the exclusive affairs of the central government in a unitary state, such as security matters. This provides a lesson for Indonesia that the issue of federalism in Aceh is indisputable and the Northern Ireland case reinforces the insight that federal state and unitary state have some degrees of similarity.
\end{abstract}

Keywords: asymmetrical decentralization, Northern Ireland, peacemaking.

\section{Desentralisasi Asimetris dan Penciptaan Perdamaian: Membandingkan Aceh dengan Irlandia Utara}

\begin{abstract}
Abstrak
Artikel ini membandingkan model desentralisasi dengan otonomi khusus Aceh, Indonesia dan devolusi di Irlandia Utara, Kerajaan Inggris sebagai bentuk desentralisasi asimetris yang berkorelasi pada penciptaan perdamaian. Secara umum, model desentralisasi di kedua daerah tersebut memiliki kesamaan latar belakang yaitu akibat konflik berkepanjangan. Namun, devolusi di Irlandia Utara jauh lebih kompleks dibandingkan di Aceh karena

PADJADJARAN Journal of Law Volume 6 Number 2 Year 2019 [ISSN 2460-1543] [e-ISSN 2442-9325]

* Assistant Professor of Constitutional Law, Faculty of Law Universitas Padjadjaran, Jl. Imam Bonjol No. 21, Bandung, S.H., M.H., Dr. (Universitas Padjadjaran), abdurahman@unpad.ac.id.

** Assistant Professor of Constitutional Law, Faculty of Law Universitas Padjadjaran, Jl. Imam Bonjol No. 21, Bandung, S.H., M.H (Universitas Padjadjaran), b.dewansyah@unpad.ac.id.
\end{abstract}


disebabkan oleh konflik keagamaan yang telah berakar secara historis dan berhubungan erat dengan negara lain yang mempengaruhi status konstitusional Irlandia Utara di kemudian hari. Hal ini berbeda dengan dengan pemerintahan Aceh yang sejak MoU Helsinki tetap menjadi bagian dari Indonesia dalam bentuk negara kesatuan. Di sisi lain, dari segi urusan pemerintahan, desentralisasi di Aceh justru mencerminkan berkurangnya kekhususan Pemerintahan Aceh, dengan pola pembagian urusan pemerintahan yang hampir sama dengan pembagian urusan pemerintahan daerah pada umumnya, berbeda dengan urusan pemerintahan Irlandia Utara yang sangat luas, menyangkut urusan yang secara tradisional dikategorikan sebagai urusan eksklusif pemerintah pusat di negara kesatuan, seperti keamanan. Hal ini memberikan pelajaran bagi Indonesia bahwa antara negara federal dan negara kesatuan memiliki persamaan-persaman dalam derajat tertentu.

Kata kunci: desentralisasi asimetris, Irlandia Utara, penciptaan perdamaian.

\section{A. Introduction}

One of the unique things in decentralization of Indonesia after the 1998 Reform is the continued assignments of special autonomy to provincial level, one of which is to Aceh. In contrast to Papua's special autonomy, which is more acceptable, ${ }^{1}$ Aceh's special autonomy arrangements have experienced vicissitudes. After the establishment of special autonomy status in 2001, numerous security operations were still conducted to force GAM (Gerakan Aceh Merdeka-the Free Aceh Movement) to accept special autonomy. ${ }^{2}$ GAM strongly rejected the implementation of special autonomy in Aceh. ${ }^{3}$ Nevertheless, the conflict between GAM and the Central Government continued until the reign of President Susilo Bambang Yudhoyono, precisely after the 2004 Tsunami disaster.

A new bright path was started after the Helsinki Memorandum of Understanding (hereinafter the 'Helsinki MoU') between Indonesian government and the GAM on August 15, 2005. ${ }^{4}$ The Helsinki MoU eventually led to the establishment of the Law Number 11 of 2006 on the Governing of Aceh (LGA hereinafter LGA) superseded the Law Number 18 of 2011 on Special Autonomy of Nangroe Aceh Darussalam (NAD) Province. Furthermore, the development of special autonomy arrangements in Aceh before the establishment of the Law Number 11 of 2006 was a process to create peace in Aceh. After the Helsinki MoU,

\footnotetext{
1 When Papua was divided into two provinces, with the formation of the Province of West Papua, the status of special autonomy was demanded by the people of West Papua. Special Autonomy for West Papua is obtained through Government Regulation in Lieu of the Law Number 1 of 2008 on the Amendment to the Law Number 21 of 2001 on Special Autonomy for the Province of Papua, stipulated by the Law Number 35 of 2008.

2 Michelle Ann Miller, Rebellion and Reform in Indonesia Jakarta's Security and Autonomy Policies in Aceh, London \& New York: Routledge, 2009, p. 127.

3 Ibid.

4 Ferry Mursyidan Baldan, Pondasi Menuju Perdamaian Abadi: Catatan Pembahasan RUU Pemerintahan Aceh, Jakarta: Suara Bebas, 2007, p. 24.
} 
the GAM no longer wants to gain Aceh's independence from Indonesia ${ }^{5}$ and pushes armed insurgency. ${ }^{6}$ Instead, they actively participated in the administration of Aceh within the framework of a unitary state. ${ }^{7}$

On peace achievement perspective, the Aceh's special autonomy arrangements and their developments have similarities with the devolution of regional governments in the Northern Ireland, UK. ${ }^{8}$ The devolution policy is a response to the prolonged armed religious and social conflicts, which led to demands for independence. After the option of self-governing (the Irish Free State) in 1922 was rejected, the Southern Ireland unilaterally declared independence by adding the Northern Ireland as part of its territory. In 1998, peace in Northern Ireland began to shed some light when the UK and the Republic of Ireland signed agreement to resolve conflicts in Northern Ireland peacefully (known as the Belfast Agreement or Good Friday Agreement). ${ }^{9}$ Based on the agreement, the two countries adjusted internal arrangements, including the British Parliament, which established the 1998 Northern Ireland Act (herein after NIA), as the basis for Northern Ireland devolution.

Conceptually, the two are referred as a form of asymmetric decentralizations. ${ }^{10}$ They are interesting to be compared, given the different developments of each system, especially in attempts to bring peace. The Aceh shows that the system is relatively successful in resolving social conflicts, and even the ex-GAM figures have succeeded to occupy strategic positions in the Aceh Government. ${ }^{11}$ On the other hand, The UK experience in Northern Ireland case still not fully achieving peace

5 Memorandum of Understanding between the Government of the Republic of Indonesia and the Free Aceh Movement (Helsinki MoU) 2005, http://www.acehpeaceprocess.net/pdf/mou_final.pdf, accessed on January 2019.

6 See Article 4 of the Helsinki MoU.

$7 \quad$ Michelle Ann Miller, op.cit., p. 161.

$8 \quad$ Leeke, Sear, and Gay says, "The progress of devolution in Northern Ireland is inextricably bound up with the peace process..". See Matthew Leeke, Chris Sear, Oonagh Gay, "An Introduction To Devolution in The UK", Research Paper 03/84, 17 November, Parliament And Constitution Centre - House Of Commons Library, London, 2003, p. 7, http://www.parliament.uk/commons/lib/research/rp2003/rp03-084.pdf, accessed on February 2010.

9 Christopher McCrudden, "Northern Ireland and The British Constitution Since the Belfast Agreement", in Jeffrey Jowell, Dawn Oliver (eds.), The Changing Constitution, Sixth Edition, New York: Oxford University Press, 2007, p. 239. See also John Alder, General Principles of Constitutional and Administrative Law, Tenth Edition, London: Palgrave Macmillan, 2015, p. 368; Matthew Leeke, Chris Sear, Oonagh Gay, ibid., p. 27; Hilaire Barnett, Constitutional and Administrative Law, Fourth Edition, London-Sydney: Cavendish Publishing Limited, 2005, p. 58.

10 In short, asymmetric decentralization or asymmetric autonomy is a concept of decentralization in which certain regions in a country are given special powers that are not given to other regions. See Bayu Krisnapati, "Desentralisasi Asimetris Dalam Negara Kesatuan Republik Indonesia", Master's Thesis, Faculty of Law Universitas Islam Indonesia, 2012, p. 9.

11 Gunnar Stange, Roman Patock, "From Rebels to Rulers and Legislators: The Political Transformation of the Free Aceh Movement (GAM) in Indonesia", Journal of Current Southeast Asian Affairs, Vol. 29, Issue 1, 2010, p. 10. 
since armed insurgency, violence, and feuds among the ruling elites still occur frequently. ${ }^{12}$

This article compares the two asymmetrical models of decentralization in their relation to peacemaking process, their backgrounds, and the substances of arrangements in the constitution and several laws.

\section{B. Decentralization in Aceh, Devolution in Northern Ireland, and the Concept of Asymmetric Decentralization}

In this article, the term decentralization refers to the Government of Aceh in Indonesia is territorial decentralization that equivalent to the term devolution in the UK. However, there are differences in the specific meanings of the two terms in Indonesian and British contexts.

In Indonesia, decentralization is understood as the distribution of government affairs by the Central Government to autonomous regions based on the principle of autonomy. ${ }^{13}$ The term devolution in the UK also includes administrative devolution, which is similar to deconcentration. ${ }^{14}$ However, in practice, the term devolution is associated with the transfer of authority to regional governments, not including local government. ${ }^{15}$ On the other hand, the term decentralization in Indonesian law covers the transfer of central authority to provincial, regency, or city governments. ${ }^{16}$ However, this article is in the position that Aceh and Northern Ireland have an equivalent position: Aceh is one of the provinces of Indonesia ${ }^{17}$ and Northern Ireland is one of the regions ${ }^{18}$ of the UK.

Both decentralization models reflect the concept of asymmetric decentralization, especially in the peacemaking process. According to Charles Tartlon $^{19}$, asymmetrical pattern is marked by "the level of conformity and commonality in the relations of each separate political unit of the system to both the system as a whole and to the component units", while in one or more

12 Christopher McCrudden, “Northern Ireland..., in Jeffrey Jowell, Dawn Oliver (eds.), op.cit., p. 242; Rick Wilford, Robin Wilson (eds.), Northern Ireland Devolution Monitoring Report, London: The Constitution Unit University College of London, 2006, p. 11, http://www.ucl.ac.uk/constitutionunit/research/devolution/MonReps/NI_May06.pdf, accessed on February 2010.

13 See Article 1(8) and (9) of Law Number 23 of 2014 on Local Government.

14 Matthew Leeke, Chris Sear, Oonagh Gay, op.cit., p. 7.

15 Eric Barendt, An Introduction to Constitutional Law, New York: Oxford University Press, 1998, p. 64; C.F. Strong, Modern Political Constitution, London: The English Language Book Society - Sidgwick \& Jackson Limited, 1966, p. 64.

16 See Article 18(1) of Second Amendment of 1945 Constitution of the Republic of Indonesia.; Article 3(1) of Law Number 23 of 2014 on Local Government (LGA).

17 Article 1 (4) of LGA.

18 Actually, there is no common term to refer to areas such as provinces in the UK. Some call them nations, countries, regions, or even sub-national units. However, this article uses the term regional area for Northern Ireland. Hilaire Barnet, op.cit., p. 365.

19 Ni'matul Huda, Desentralisasi Asimetris dalam NKRI Kajian terhadap Daerah Istimewa, Daerah Khusus dan Otonomi Khusus, Bandung: Nusamedia, 2014, p. 59. 
asymmetrical pattern marks for local politics or government is "possessed of varying degrees of autonomy and power". ${ }^{20}$ Substantially, asymmetric decentralization occurs when local governments at the same level have different political, administrative, and fiscal powers. ${ }^{21}$

Although asymmetric decentralization is not a panacea, but it contributes to peace-building efforts, ${ }^{22}$ to resolve central-regional conflicts. ${ }^{23}$ The two cases compared in this study show that the asymmetric decentralization represents a peace agreement to maintain territorial integrity of country from the separatist movements. ${ }^{24}$ Although this asymmetric model can be applied both in unitary and federal state, ${ }^{25}$ the asymmetric decentralization models in Aceh and Northern Ireland reveals that Indonesia and the UK use a loose model of central and regional relations that close to a federation model to maintain the form of unitary state.

Generally, in Indonesian decentralization, different arrangements are made possible. The state's constitution recognizes regional government units that have specificity and privileges ${ }^{26}$, including, in this case, the Government of Aceh. Among others, the Aceh is unique because it is a result of a peacemaking process and based on the idea of self-government. ${ }^{27}$ In the UK, Northern Ireland model called as devolution plus because it is different from the general decentralization, or because the Belfast Agreement is an attempt to improve devolutions of Scotland and Wales, or because the document is an international agreement between the UK and the Republic of Ireland that involved two sovereignties, two states. ${ }^{28}$

\section{The Backgrounds of Asymmetrical Decentralization and Conditions for the Peacemaking Process in Aceh and Northern Ireland}

The background of asymmetric decentralization of Aceh is inseparable from the Indonesian post-independence conflicts. In 1953, Aceh experienced insurgency by the Darul Islam rebellion, led by Daud Beureuh. This was a response to the

$20 \quad$ Ibid.

21 CFE OECD, "Asymmetric decentralisation: Policy implications in Colombia", 2019, p. 20, http://www.oecd.org/countries/colombia/Asymmetric_decentralisation_Colombia.pdf, accessed on June 2019.

22 H. F. Larsen and N. Selim, "Local Democracy and Peace Building in Asia: Devolution Arrangements and Power Sharing in Local Government Councils", background paper for Regional Technical Seminar on Local Governance and Basic Service Delivery in Conflict Affected Areas, Bangkok, June 2-3, 2009, p. 1.

23 International IDEA \& Constitution Transformation Network, "Asymmetric Territorial Arrangements in Decentralized Systems", Constitutional INSIGHTS No. 3, October 2018, p. 3, https://www.idea.int/sites/default/files/publications/asymmetric-territorial-arrangements-in-decentralizedsystems.pdf, accessed on January 2019.

24 H. F. Larsen, N. Selim, op.cit., p. 3.

25 International IDEA \& Constitution Transformation Network, op.cit., p. 5.

26 See Article 18B(1) of the Second Amendment of 1945 Constitution of the Republic of Indonesia.

27 Aceh "Aceh: Feature, Kesatuan", http://www.acehfeature.org/index.php/site/detailartikel/301/Aceh,-Federalisme-atau-Negara-Kesatuan/, accessed on April 2010.

28 Christopher McCrudden in Jeffrey Jowell, Dawn Oliver (eds.), op.cit., pp. 267-268. 
integration of the Aceh Province into the Province of North Sumatra that makes it impossible for Aceh to implement Sharia Law. While, President Soekarno promised in early period of independence that Aceh would have a special status of autonomy and special rights, including the implementation of Sharia Law. ${ }^{29}$ The conflict eventually was ended after the Soekarno government granted the special region status to the Aceh Province, including the power to regulate religious matters based on the Decree of the Prime Minister Number 1/Misi/1959, which was confirmed by the Law Number 18 of $1965 .{ }^{30}$

But, the implementation of Sharia Law in Aceh was ineffective, partly because regional regulations that contain Sharia values did not get authorization from the competent authority, ${ }^{31}$ in this case the Minister of the Interior Affairs. ${ }^{32}$ Dissatisfaction among the people of Aceh continued during the New Order Era, which tended to be secular and centralized. Further, the socio-economic inequality caused large-scale unrest in the province. ${ }^{33}$ The momentum was used by the GAM to demand Aceh's independence with a "non-negotiable" approach. ${ }^{34}$ The organization was founded by Tengku Hasan Muhammad di Tiro, known as Hasan di Tiro, a successful businessman who once declared himself as Darul Islam's "Ambassador" to the United Nations. ${ }^{35}$ At the beginning, it was only small-scaled armed rebellion. ${ }^{36}$ However, in 1989, the movement began to revive. Their guerrillas, which were initially dominated by unemployed youth who mostly are from peasant families, received support from various community members, as well as weapons and training back-up from Gadhafi's Libya. ${ }^{37}$

In response, the New Order government used a military approach to suppress GAM's by declaring Aceh as a Military Operations Area (DOM-Daerah Operasi Militer), which led to various human rights violations that ended in mid-1998. After the 1998 Reform, the central government initiated peaceful conflict resolution to settle the Aceh insurgency..$^{38}$ Unfortunately, once again the militaristic approach became very dominant after President Megawati Soekarno Putri came to power. She re-introduced the policy of DOM in Aceh in 2003. ${ }^{39}$ However, during her reign, Aceh also was given specific autonomy status by changing the designation of Aceh Province to Nanggroe Aceh Darussalam (NAD), or literally, "the State of Aceh,

\footnotetext{
Angel Rabasa, Peter Chalk, Indonesia's Transformation and the Stability of Southeast Asia, Santa Monica: RAND, 2001, p. 29; Ni'matul Huda, op.cit., pp. $226-231$.

See Article 88 of Law Number 18 of 1965 on Basic Regulation of Local Government.

Bagir Manan, Menyongsong Fajar Otonomi Daerah, 3rd ed, Yogyakarta: PSH FH UII, 2004, p. 15.

See Article 78 of Law Number 18 of 1965 on Basic Regulation of Local Government.

Angel Rabasa, Peter Chalk, op.cit., pp. $28-29$.

Ibid., p. 29.

Michelle Ann Miller, op.cit., p. 5.

Angel Rabasa, Peter Chalk, op.cit., p. 29.

Theodore Friend, Indonesian Destinies, Cambridge, Massachusetts: Harvard University Press, 2003, p. 271.

Michelle Ann Miller, op.cit., p. 14.

Ibid., p. 102; Ni'matul Huda, op.cit., p. 242.
} 
Abode of Peace" based on the Law Number 18 of 2001. Previously, the status of Aceh as a Special Region was "restored" through the Law Number 44 of 1999, including in terms of Islamic law implementation. ${ }^{40}$ However, the NAD Special Autonomy Law did not work effectively due to the Central Government views which distrust special autonomy. ${ }^{41}$ The law was also rejected by GAM and SIRA, a civil society organization established by Aceh students and youths backing up Aceh referendum, because it was seen as a unilateral offer from Jakarta without any compromises. $^{42}$

In the end, the peace agreement was reached after the 2004 Tsunami through the Helsinki MoU, during the reign of President Susilo Bambang Yudhoyono. ${ }^{43}$ Previously, peace negotiation efforts had been carried out but the implementation was always failed due to different interpretations, or because they did not reach an agreement. One of the efforts was the CoHA (Cession of Hostilities Agreement) that was signed by the Government of Indonesia and the GAM in Switzerland. CoHA was a plan to renegotiate with the help of the Henry Dunant Center in 2003, which was failed to be implemented. ${ }^{44}$

Aside from being a peace agreement, the Helsinki MoU also reflects agreement on several key matters. It includes the establishment of new laws about Aceh which increase the political participation (the formation of local political parties, free and fair local elections to elect Aceh's regional heads and representative bodies, including for national elections), reforming the economic sector (including fair distribution of natural resources), strengthening human rights enforcement (including the establishment of special courts for Aceh and the Aceh Truth and Reconciliation Commission, granting amnesty and reintegration of ex-combatants of GAM), security (specifically decommissioning weaponry, ammunition, and explosives), and the establishment of the Aceh Monitoring Mission (AMM). ${ }^{45}$

In Northern Ireland, the devolution is related closely to the history of the UK establishment in the past. Northern Ireland is a region of the UK, in addition to England, Wales, and Scotland (the Great Britain). ${ }^{46}$ However, it was originally part of Ireland, which since 1800 joined the Great Britain ${ }^{47}$ to form the United Kingdom. ${ }^{48}$ The integration of Ireland to the UK was an effort to resolve a prolonged conflict between the Irish Catholic community and the Protestant community in the Great Britain. ${ }^{49}$ After a series of conflicts, the Parliament of the UK divided Ireland into

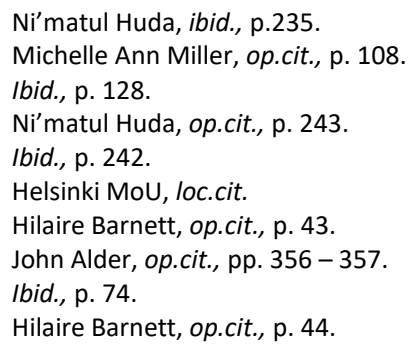


Northern Ireland, which are predominantly Protestant, and Ireland in the southern region, under the Government of Ireland Act in $1920 .^{50}$ Since then, the Northern Ireland becomes a region that has its own representative body and government. The other parts of Ireland (The Irish Free State) gained status as a British dominion in $1922 .^{51}$

However, the decision did not resolve the conflict. A militia of the Irish Volunteers (republican group) known as the Irish Republican Army (IRA) carried out series of attacks. ${ }^{52}$ It led to a civil war from 28 June 1922 until $1923 .{ }^{53}$ Armed conflict continued even after Ireland had become fully independent from the UK by the establishment of the Republic of Ireland based on the 1937 Constitution of the Republic of Ireland. Only later, the British Parliament, in accordance with The 1949 Ireland Act, recognized the free Irish state. ${ }^{54}$

The conflicts were also triggered by the 1937 Constitution of the Republic of Ireland. The Republic of Ireland unilaterally declared Northern Ireland as a part of the Republic of Ireland. On the other hand, the recognition of the UK of the independence of the Republic of Ireland does not include the Northern Ireland region. The insurgency continued until $1969 .{ }^{55}$ In 1972, the authority of the Northern Ireland Parliament was taken over by the British Parliament ${ }^{56}$ and the administration was taken over by the Central Government through the State Secretary for Northern Ireland. ${ }^{57}$ The moment triggered the murders of British soldiers by the republican group. ${ }^{58}$

Attempts to discuss home rule in the British Parliament had been carried out since 1983, but they all failed because of the conflict between the Protestant and Catholic factions in the Parliament and because of horizontal conflicts within the people. ${ }^{59}$ Efforts to bring peace in Northern Ireland began to shed some light in 1998 when the UK and the Republic of Ireland signed agreement to resolve conflict in Northern Ireland peacefully (the Belfast Agreement/Good Friday Agreement). ${ }^{60}$

\footnotetext{
Ibid., p. 51.

51 The status of Ireland as a British dominion is the result of the Articles of Agreement of 1921 between the Parliament of the UK and the Irish delegation. Under the agreement, the Northern Ireland Parliament was given the choice to join or not join. Ibid.

52 M. L. R. Smith, Fighting for Ireland? The Military Strategy of the Irish Republican Movement, London: Routledge, 1995, p. xiv.

Ibid.

Ibid., p. 52.

George Childs Kohn (ed.), Dictionary of Wars, Third Edition, New York: Facts On File Inc., 2007, p. 372.

Ibid.

Hilaire Barnett, op.cit., p. 55.

Ibid.

Ibid.

60 Christopher McCrudden, "Northern Ireland and The British Constitution since The Belfast Agreement", in Jeffrey Jowell, Dawn Oliver (eds.), The Changing Constitution, $6^{\text {th }}$ Ed, New York: Oxford University Press, 2007, p. 239; John Alder, op.cit., p. 368; Matthew Leeke, Chris Sear, Oonagh Gay, op.cit., p. 27; Hilaire Barnett, op.cit., p. 58.
} 
Based on the agreement, the two countries adjusted internal arrangements. The British Parliament adopted the 1998 NIA, which asserted that Northern Ireland remained part of the UK and only majority voters can change the status of Northern Ireland. ${ }^{61}$ If the majority voters tend to choose joining the Republic of Ireland, the Secretary of State will submit a proposal to the Government of the Republic of Ireland. ${ }^{62}$ On the contrary, the Republic of Ireland changed two of its constitutional articles regarding the territory of the country and the clauses of the application of the Republic of Ireland's laws in Northern Ireland. ${ }^{63}$ The agreement also resulted in the formation of two joint institutions between the UK and the Republic of Ireland (BIC and BIIC) and between Northern Ireland and the Republic of Ireland (NSMC). ${ }^{64}$ Based on the 1998 NIA, the Northern Ireland Assembly and Executive has the authority to regulate transferred matters. ${ }^{65}$ In addition there are excepted matters, namely matters that becomes the central authority only; and reserved matters, which are central matters that can become the authority of the Northern Ireland if there is agreement from the people of Northern Ireland. ${ }^{66}$

In practice, the peace agreement did not run smoothly. Devolution of Northern Ireland was suspended temporarily due to the IRA's attack in 2000 and internal conflicts among the Republicans in $2005 .{ }^{67}$ The devolution of Northern Ireland was re-applied in 2006 (NIA 2006), many unexpected things were happened after that, including the stagnancy of the Northern Ireland government since 2017 due to the conflict of the two major political parties that control the Northern Ireland government. ${ }^{68}$ The peacemaking process in Northern Ireland will still develop in the future, including the constitutional status of Northern Ireland. ${ }^{69}$ This is different from the decentralization in Aceh. Since the Helsinki MoU and the LGA, it has

61 John Alder, ibid., p. 369.

62 Ibid.

63 John Doyle, "Towards a Lasting Peace?: the Northern Ireland multi-party agreement, referendum and Assembly elections of 1998", Scottish Affairs, 1998, p. 2, accessed from http://ssrn.com/abstract=1297928, on February 2010.

64 Christopher McCrudden, “Northern Ireland..., in Jeffrey Jowell, Dawn Oliver (eds.), op.cit., pp. 241-242.

65 Matthew Leeke, Chris Sear, and Oonagh Gay, op.cit., p. 28.

66 Ibid., pp. 28-29; Connie Smith, "Devolution in the UK: Powers and Structures in Scotland, Wales and Northern Ireland", Artikel Briefing No. 1, The University of Edinburgh, 2008, p. 3, http://www.clicp.ed.ac.uk/publications/briefings/briefing01.pdf, accessed on February 2010.

67 These include the murder of Sinn Fein's (republican) party leader, Dennis Donaldson, by the IRA spies in 2005. See Rick Wilford, Robin Wilson (eds.), Northern Ireland Devolution Monitoring Report, London: The Constitution Unit - University College of London, 2006, p. 11, http://www.ucl.ac.uk/constitutionunit/research/devolution/MonReps/NI_May06.pdf, accessed on February 2019.

68 The Independent, "Why is there no government in Northern Ireland and how did power-sharing collapse?", https://www.independent.co.uk/news/uk/politics/northern-ireland-talks-latest-updates-stormont-powersharing-deal-what-deal-look-sinn-fein-dup-deal-a8711691.html, accessed on February 2019. 
experienced positive developments in terms of the peacemaking process and the relationship between the Central Government and the Aceh region. ${ }^{70}$

\section{Constitutional and Legal Framework for the Governances of Aceh and Northern Ireland}

The asymmetrical arrangement of Aceh and Northern Ireland has similarities because they are regulated in specific laws, namely the 2006 LGA and the 1998 NIA. The two laws regulate a number of specificities, compared to other regions in general or those of a special nature, such as Wales and Scotland in the UK, which emphasize differences of national identity ${ }^{71}$, as well as Papua and Yogyakarta in Indonesia, which is based on cultural features.

The new Aceh Government model based on the LGA, which replaces the Law Number 18 of 2001 does not lead Aceh to lose its special autonomy. Aceh's special autonomy, based on LGA, is even broader than the NAD Special Autonomy Law. Under the NAD Special Autonomy Law, Aceh has special autonomy in finance (local revenue from zakat, special autonomy funds), authority to determine regional symbols, the existence of adat institutions (Wali Nangroe and Tuha Nangroe), specificity in the field of justice (the presence of the Sharia Court), privilege in the appointment of certain positions of central government in the region (such as the Head of the Regional Police and the Head of the High Prosecutors Office), and the direct election of local leaders (governors, regents, and mayors held by the Independent Election Commission-KIP). In the 2006 LGA, the specificities contained in the previous law are maintained. However, it also covers other specificities to accommodate the agreements in the Helsinki MoU. Such as, allowing local political parties to participate in regional elections at the provincial, regency, and city level; the existence of independent candidates in the election of local leaders (governor and deputy governor, regent and deputy regent, mayor and deputy mayor); authority to cooperate with foreign bodies or institutions - except those under the authority of the central government; as well as consultation and consideration from the Aceh House of Representatives (DPRA) in terms of international agreement that is directly related to Aceh.

70 This does not neglect GAM internal conflicts after they are transformed into the Aceh Transitional Commission (KPA), and the conflict between the Governor and the Aceh Parliament. Pusat Studi Perdamaian dan Resolusi Konflik - Universitas Syiah Kuala, "Laporan Pemantauan Perdamaian Aceh", 2009, pp. 3-4., https://jgrayman.files.wordpress.com/2010/05/laporan-pemantauan-perdamaian-aceh-sep-dec2009.pdf accessed on June 2019. Another thing that caused tension in Aceh, was the demand for the formation of the Provinces of Aceh Lauser Antara (ALA) and Aceh Besar Selatan (ABAS), which were demands for the division of Aceh. See Bilal Dewansyah, Giri Ahmad Taufik, "Konsepsi Pemekaran Aceh (ALA, ABAS) dan Pengaruhnya Terhadap Peningkatan Kesejahteraan dan Kehidupan Kultural Masyarakat", paper presented in 7th International Seminar on Local Politics Dynamic , Lembaga Percik - Ford Foundation, Salatiga, July 17 - 19, 2007.

71 John Curtice, "A Stronger or Weaker Union? Public Reactions to Asymmetric Devolution in the UK", The Journal of Federalism, Vol. 36, No. 1, 2006, pp. 97-102. 
Substantially, the 1998 NIA has been amended several times. ${ }^{72}$ It regulates a number of important matters, such as the status of Northern Ireland, its governmental matters (transferred, excepted, and reserved matters), Northern Ireland Assembly's legislative powers with a number of restrictions, executive power of Northern Ireland (consisting of First Minister, Deputy First Minister and Ministers, including departments, positions, elections, and powers of the Northern Ireland Assembly), British and Irish cooperation bodies for the implementation of the Belfast Agreement (the North-South Ministerial Council -NSMC, British-Irish Council-BIC, British-Irish Intergovernmental Conference -BIIC), financial power, and provisions on human rights.

From the regulatory perspective, both the 2006 LGA and the 1998 NIA have a number of similarities in affirming governmental matters, the institutional structure of the regional government, and the guarantee of human rights. It can be ensured that human rights provisions in both laws are highly correlated with efforts of peacemaking process.

However, there are fundamental differences in the law that regulates Aceh and Northern Ireland. First, the 1998 NIA specifically regulates the implementation of the Belfast Agreement, thus making the agreement an inseparable part of the law. On the other hand, the 2006 LGA does not specifically regulate Helsinki MoU implementation, and only mentions it once in the elucidation section of the law. The ignorance the Helsinki MoU content in the 2006 LGA has caused tension among the political elites, especially between the former GAM leaders and the Government. ${ }^{73}$

Based on constitutional guarantees, despite the fact that the two regions are equivalent, there are important differences. In Indonesia, the existence of provincial government (including autonomous regions) is guaranteed constitutionally in the documentary constitution. The existence of special autonomy is regulated in Article 18B (1) of the Second Amendment to the 1945 Constitution. It mentions that "the State shall recognize and respect entities of regional administration that possess a specificity or a distinctiveness that are to be regulated by law". Before the Second Amendment, the idea of special autonomy was developed as an offer to Timor Leste, which demanded independence in 1999 and gained it in 2002. ${ }^{74}$ This is different from the concept of the UK's devolution since there is no strong constitutional guarantees for it, resulting to the withdrawal and suspension of devolution for several times by the Central Government. ${ }^{75}$

\footnotetext{
72 Northern Ireland Act (NIA) 1998 and Amendment, https://www.legislation.gov.uk/ukpga/1998/47/contents, accessed on June 2019.

73 Ferry Mursyidan Baldan, op.cit., pp. $32-37$.

74 Angel Rabasa and Peter Chalk, op.cit., pp. 21 - 23; Colin Brown, A Short History of Indonesia: The Unlikely Nation?, New South Wales: Allen \& Unwin, 2003, p. 233.

75 George Childs Kohn (ed.), loc.cit; Hilaire Barnett, op.cit., p. 55.
} 
On the other hand, Indonesian decentralization reflects a rigid nature because the provinces are governed based on uniformity principles. The devolution in the UK shows a non-uniformity arrangement, although in certain cases there are similarities. ${ }^{76}$ In this case, each regional government in the UK has its own uniqueness.

Table 1. Similarities and differences between Aceh's and the Northern Ireland's devolution

\begin{tabular}{|l|l|l|}
\hline No. & Similarities & Differences \\
\hline 1. & Regulated in a separate law & $\begin{array}{l}\text { Specificity and privileges of Aceh, as } \\
\text { well as other similar regions, have } \\
\text { constitutional guarantees. The } \\
\text { British's devolution in general has } \\
\text { no guarantees in the constitution. }\end{array}$ \\
\hline 2. & $\begin{array}{l}\text { A number of important materials } \\
\text { are arranged. They cover } \\
\text { government affairs, institutions } \\
\text { and powers, and human rights. }\end{array}$ & $\begin{array}{l}\text { The } 2006 \text { LGA does not regulate the } \\
\text { implementation of the Helsinki } \\
\text { MoU. The NIA regulates the bodies } \\
\text { resulted from the agreement. }\end{array}$ \\
\hline
\end{tabular}

\section{E. Constitutional Status of the Governments of Aceh and Northern Ireland}

After the Helsinki MoU, GAM's struggle has been transformed. ${ }^{77}$ Currently, GAM accepts the peace with the Government of Indonesia. ${ }^{78}$ The Belfast Agreement is also a peace agreement to resolve the insurgency in Northern Ireland. However, there are a difference, the Helsinki MoU is not an international agreement, ${ }^{79}$ while the Belfast Agreement can be considered as an international agreement since the main subjects in the agreement are states (the UK and the Republic of Ireland). ${ }^{80}$ The Helsinki MoU only involves two parties (the Government of Indonesia and GAM). The former Finnish President, Martti Ahtisaari, ${ }^{81}$ facilitated the MoU in his capacity as the Chairman of the Crisis Management Initiative Board of Directors. Meanwhile, The Belfast Agreement, in the process, also involved other parties,

76 The main similarity of arrangement among the regional governments is in terms of central financial transfers to the regions by using a formula called the Barnett Formula. Matthew Leeke, Chris Sear, and Oonagh Gay, op.cit., p. 9.

77 The mission has been carried by GAM in leadership since the organization was founded in 1976. See International Crisis Group (ICG), "Aceh: Can Autonomy Stem the Conflict?", ICG Asia Report, No. 18, 2001, p. 2.

78 The Preamble of the Helsinki MoU, loc.cit.

79 Article 1 point 1 Law Number 24 of 2000 on International Treaties. In this case, GAM is not a subject of international law, for example having the status of a rebel given the right to fight (belligerent) or in disputes with a legitimate government. See J.G. Starke, Pengantar Hukum Internasional, $10^{\text {th }}$ Ed, translated by Bambang Iriana Djajaatmadja, Jakarta: Sinar Grafika, 2000, p. 87.

80 Christopher McCrudden, “Northern Ireland .......”, in Jeffrey Jowell, Dawn Oliver (eds.), op.cit., p. 233.

81 See Helsinki MoU, loc.cit. 
such as the nationalist, Sinn Fein (a Political Party with a close relationship with the IRA) and other political parties from the unionist group. ${ }^{82}$

The involvement of the two groups in Northern Ireland, is needed to stop paramilitary activities in Northern Ireland. On the other hand, it reflects the recognition of the nationalist group's objective that Northern Ireland would join the Republic of Ireland in the future. This reflects the issue of the constitutional status of Northern Ireland that has not yet been firmly determined. ${ }^{83}$ The Belfast Agreement agrees, "the legitimacy of whatever choice is freely exercised by the majority of the people of Northern Ireland with regard to its status, whatever they prefer to continue to support the Union with Great Britain or a sovereign united Ireland". ${ }^{84}$ Despite the fact that the Belfast Agreement stipulates that the constitutional status of Northern Ireland is determined by the wishes of the people of Northern Ireland, the 1998 NIA emphasizes that Northern Ireland is a part of the UK. Further, it also stipulates that the status cannot be changed without the approval of the majority of the people through a poll..$^{85}$ This shows the interest to keep the Northern Ireland to be a part of the UK. Moreover, the authority to determine the poll lies in the hands of the UK Minister of Interior. ${ }^{86}$ In other words, the Secretary of State could have refused to conduct a poll even though the majority of the people want the poll of self-determination. This is different from Aceh status that based on the Helsinki MoU ${ }^{87}$ and confirmed in the 2006 LGA, ${ }^{88}$ it is a part of Indonesia with in unitary state framework.

The nationalist groups of Northern Ireland have never demanded the referendum on the status of Northern Ireland. In contrast, unionists, demanded the referendum. ${ }^{89}$ Even when a poll was conducted on February 19, 2003 to see the preferences of the people, only one-third of Protestants of Northern Ireland supported the Belfast Agreement. ${ }^{90}$ However, the constitutional status of Northern Ireland can be changed in the future.

\footnotetext{
Christopher McCrudden, “Northern Ireland ......., in Jeffrey Jowell, Dawn Oliver (eds.), op.cit., p. 238.

Ibid., p. 233.

Belfast Agreement, Constitutional Issues, 1 (i), ibid.

See Article 1(1) of the 1998 NIA.

86 Article 1(2) of the 1998 NIA said "But if the wish expressed by a majority in such a poll is that Northern Ireland should cease to be part of the UK and form part of a united Ireland, the Secretary of State shall lay before Parliament such proposals to give effect to that wish as may be agreed between Her Majesty's Government in the UK and the Government of Ireland". In the Schedule 1 number (1) of the 1998 NIA,"The Secretary of State may by order direct the holding of a poll for the purposes of section 1 on a date specified in the order".

87 See paragraph 2 of Helsinki MoU, loc.cit.

88 See Article $1(2)$ of the LGA.

89 BBC News, "Northern Ireland chronology: 2002", http://news.bbc.co.uk/2/hi/uk_news/northern_ireland/2933949.stm, accessed on February 2010.

90 Ibid; BBC News, "Northern Ireland Chronology: 2003",
} http://news.bbc.co.uk/2/hi/uk news/northern ireland/2933951.stm, accessed on February 2010. 
In Aceh, the issue that was developed after the Helsinki MoU was related to the idea of self-government, ${ }^{91}$ which was emerged during the discussion of the Aceh Government Bill. Hidayat considers that the term "self-government" originates from the idea of federalism. ${ }^{92}$ He sees the idea as being in accordance with the intention of the Helsinki MoU, which embraced the spirit of federalism by giving a full autonomy. ${ }^{93}$ A number of constitutional law scholars and political scientists also see the spirit of federalism. ${ }^{94}$ Sri Soemantri, for instance, questioning the government's and the Parliament's decisions related to Aceh that should be made after a consultation with and by the approval of the Governor of Aceh. ${ }^{95}$ According to Soemantri, such action is not needed under the unitary state. ${ }^{96}$ In its development, the title of the Law was agreed to be called the Law on "the Governing of Aceh". The idea that the Governor should give approvals in central government's and parliament's decisions are still accommodated. ${ }^{97}$ GAM seems to be satisfied with the Law since it accommodates certain privileges. The existence of Aceh in the form of a unitary state so far has not been questioned. Even when the Aceh's terrorism issue appeared in 2010, the Governor of Aceh, Irwandi Yusuf, firmly states that it had nothing to do with GAM. ${ }^{98}$

The above discussion shows that on the one hand there is the constitutional status of Northern Ireland which is still part of the UK, although in the future the status may change. On the other hand, Aceh is a part of the Indonesia as a unitary state and GAM accept this as their idea of self-government is accommodated in the 2006 LGA.

\section{F. Governmental Matters}

One of the unique things of the Government of Aceh from other regional governments lie in terms of governmental matters. Based on the LGA, there are matters related to Islamic and customary Law as follows: ${ }^{99}$

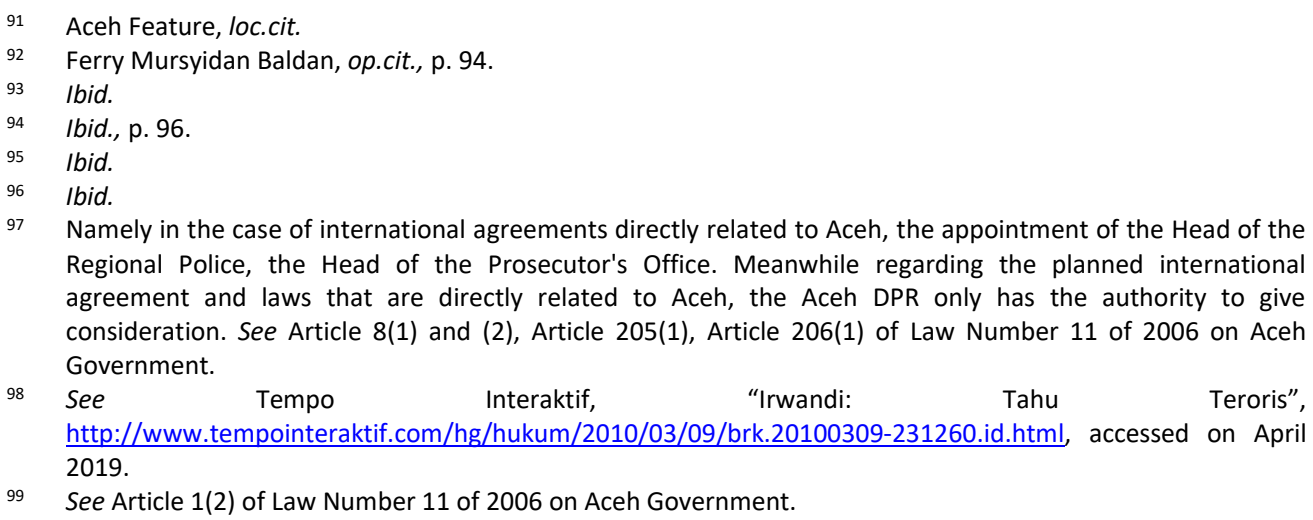
agreement and laws that are directly related to Aceh, the Aceh DPR only has the authority to give consideration. See Article 8(1) and (2), Article 205(1), Article 206(1) of Law Number 11 of 2006 on Aceh Government.

98 See Tempo Interaktif, Trwandi: Tahu Teroris", http://www.tempointeraktif.com/hg/hukum/2010/03/09/brk.20100309-231260.id.html, accessed on April 2019.

99 See Article 1(2) of Law Number 11 of 2006 on Aceh Government. 
1. the organization of religious life in the form of the implementation of Islamic Sharia Law for Muslims in Aceh while maintaining the harmony among the religious adherents;

2. the organization of traditional life based on Islam;

3. the organization of quality education and the addition of local content in accordance with Islamic sharia law;

4. the role of ulama (Muslim Scholars) in determining Aceh's policies; and

5. the organization and the management of the Hajj pilgrimage in accordance with effective regulations.

In fact, these matters are not different from the Special Autonomy Law on NAD. ${ }^{100}$ The division of governmental matters in the LGA is almost similar to the Law on Regional Governments. For example, there are compulsory matters and optional matters, while matters related to Islamic sharia and customs are referred to as other obligatory matters. ${ }^{101}$ Other than the matters, the Government of Aceh has no authority to regulate certain matters, which belongs to the central government, namely foreign policy, defense, security, justice, monetary, national fiscal, and certain matters in the religious field. ${ }^{102}$

In contrast, other special authorities, such as management of ports or public airports, lie on the regency or city, not in the Aceh province. ${ }^{103}$ The implementation of Aceh Government affairs is guided by the norms, standards, and procedures, as well as supervision of the Central Government. ${ }^{104}$ The existence of norms, standards, and procedures in the future is a general pattern in the implementation of government affairs as regulated in the Government Regulation Number 38 of 2007, which is reaffirmed in the Law Number 23 of $2014 .{ }^{105}$ Nevertheless, there is actually a presumption that the nuance of federalism in the LGA is undisputed. In federal states, the interference of the Central Government in the implementation of state government affairs is not regulated explicitly. ${ }^{106}$

Special privilege lies in matters that are not referred as the affairs of the Government of Aceh, for example in terms of revenue sharing funds from hydrocarbons and natural resources. ${ }^{107}$ In addition, other specificities are related

100 In this context, the existence of the Sharia Court based on the Special Autonomy Law on NAD based on Law Number 44 of 1999.

101 See Article 16 and Article 17 of Law Number 11 of 2006 on Aceh Government.

102 See Article 7(2) of Law Number 11 of 2006 on Aceh Government.

103 See Article 19(1) of Law Number 11 of 2006 on Aceh Government.

104 See Article 11(1) of Law Number 11 of 2006 on Aceh Government.

105 See Article 9(1) of Government Regulation Number 38 of 2007 on Division of Government Affairs between the Government, Provincial Governments, and Regency/City Governments. Compared with Article 16(1) of Law Number 23 of 2014 on Local Government.

106 However, when the central government regulates matters which are not explicitly the authority of it and the state submits a lawsuit, it will be determined by the court's decision. See Eric Barendt, op.cit., p. 52.

107 The share of Aceh in terms of natural resource management reaches $80 \%$ (Article 181 of the LGA). This is different from the provision of natural resource revenue-sharing funds as stipulated in Law Number 33 of 2004, which distinguishes the percentage of regional shares based on the type of natural resources. This is 
to the appointment of central government officials in Aceh. This shows a strong concern to regulate the pattern of relations between the Central and the Aceh governments. Even in other respects, the specificity of Aceh lies precisely in matters related to the peacemaking process, such as the regulation of human rights in Aceh. However, the provisions regarding human rights have been regulated in the 1945 Constitution and Laws. ${ }^{108}$ Based on these conditions, it should not be regulated in the LGA. ${ }^{109}$ In this case, the governance arrangements of Aceh should not be too focused on the specificity of government affairs but it should rather show the efforts of peacemaking in Aceh.

In contrast to Aceh, the division of governmental matters between the UK and Northern Ireland reveals the differences with other regional governments. ${ }^{110}$ It cover excepted matters, reserved matters, and transferred matters. ${ }^{111}$ Excepted matters are matters of the UK that cannot be under the authority of the Northern Ireland government. They include: ${ }^{112}$

1. the Crown;

2. parliamentary elections, and Assembly elections including the franchise;

3. international relations;

4. defense of the realm;

5. honors;

6. nationality;

7. national taxation;

8. appointment and removal of judges

9. registration of political parties;

10. coinage etc;

11. national security;

12. nuclear energy and installations;

13. regulation of sea fishing outside Northern Ireland;

14. provisions dealt with in the Northern Ireland Constitution Act 1973; and

15. the subject matter of the NIA 1998 with specified exceptions.

also different from the reception in the context of special autonomy for Papua which is limited to the period of its granting ( 25 years since the special autonomy of Papua was granted). See Article 34 paragraph (3) Law Number 21 of 2001 on Special Autonomy of Papua Province.

108 Law Number 39 of 1999 on Human Rights; Law Number 26 of 2000 on Human Rights Court.

109 Soemantri also mentions this in the discussion of the Aceh government bill. See Ferry Mursyidan Baldan, op.cit., p. 96.

110 For instance, Wales dan Scotland do not have reserved matters. See Matthew Leeke, Chris Sear, and Oonagh Gay, op.cit., p. 8.

111 Article 4 (1) The 1998 NIA.

112 Schedule 2 The 1998 NIA. 
Reserved matters are affairs that left to the Northern Ireland government after obtaining the agreement of two community representatives (Unionist and Nationalist). They include ${ }^{113}$

1. criminal law;

2. policing;

3. prisons;

4. civil aviation;

5. navigation;

6. the Post Office;

7. disqualification from membership of the Assembly;

8. emergency powers;

9. civil defense;

10. consumer protection;

11. telecommunications;

Lastly, transferred matters are central government affairs that are left to the Northern Ireland government. ${ }^{114}$ These matters are not explicitly determined but their implementation is based on an MoU between the central and the Northern Ireland governments (Devolution Guidelines), ${ }^{115}$ it includes: ${ }^{116}$

1. finance and personnel;

2. health, social services and public safety education;

3. agriculture and rural development;

4. enterprise, trade and investment;

5. environment;

6. culture, arts and leisure;

7. learning and employment;

8. regional development;

9. social development;

The arrangements for the governments of Aceh and Northern Ireland in certain respects reflect similarity. For instance, the Aceh Government has no authority to regulate and to manage certain central government matters, as well as excepted matters in the devolution of Northern Ireland. However, in terms of the content there are differences. For example, domestic security matters cannot be put under the authority of the Aceh Government. On the contrary, such affairs in Northern Ireland are matters that have become the authorities of the Northern Ireland Government. ${ }^{117}$ In the Aceh Government, the police matter in certain cases must

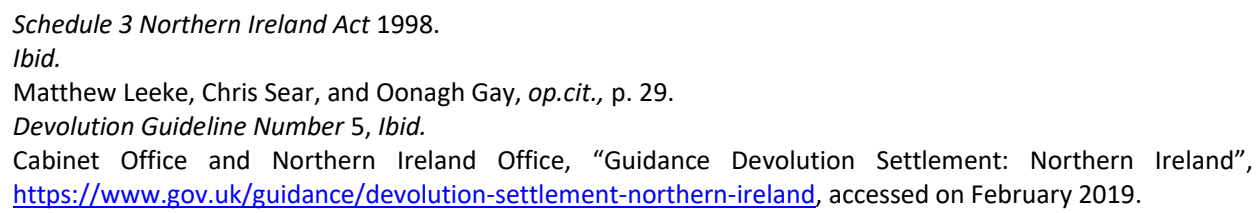


obtain the Governor's approval as mentioned earlier, for instance, regarding the appointment of the Aceh Regional Police Head. In Northern Ireland, although the handover of police affairs is carried out, the reforms of the police sector in Northern Ireland are only done in terms of the proportion of membership determination based on religion (Protestant and Catholic). ${ }^{118}$

In the case of governmental matters that are devolved, there are differences in terms of regulation. The government matters, which become the authority of the Aceh Government other than compulsory matters, are regulated in the Regional Government Law. In connection with the development of a similar arrangement of the division of regional government affairs, Aceh's government affairs become similar to other regions. ${ }^{119}$ By applying the pattern of implementation of Northern Ireland Government affairs based on the agreement, the types of Northern Ireland government matters are more flexible in accordance with the agreement between the Central and Northern Ireland governments.

\section{G. Conclusion}

This article does not cover all aspects of asymmetric decentralization in the two regions. However, a number of aspects can be concluded from the discussion. In general, asymmetrical decentralization in Aceh and Northern Ireland reflects similarities in which both are carried out as efforts of peacemaking process. However, the Northern Ireland case reflects more complex problems, since it is carried out among different countries. This affects the constitutional status of Northern Ireland, which is still may change in the future. On the one hand, Northern Ireland is a part of the UK but, it does not rule out the possibility of Northern Ireland joining the Republic of Ireland to become a united Ireland. This is different from the Aceh, which, since the Helsinki MoU, remains a part of Indonesia in the form of a unitary state. Although there is a value of federalism in the provisions of the LGA, but in other provisions, the Government of Aceh is a subject to the general pattern of regional governance in Indonesia. This reduces the Government matters of the Aceh, with a pattern of division of government affairs that is almost similar to the ordinary regional government. This is contrast with the government affairs in the Northern Irish government, that generally the authority of the central government is handed over with the agreement of the two communities. Even in the case of government affairs that are under the authority

118 Based on the Police Act 2000 (Northern Ireland), the proportion of recruitment of members of the Police in Northern Ireland is balanced between Protestants and Catholics (50:50\%). See Christopher McCrudden, "Northern Ireland..., in Jeffrey Jowell, Dawn Oliver (eds.), op.cit., p. 252.

119 After the 1998 Reformation, the tradition of dividing government affairs began since Government Regulation Number 38 of 2007, under Law No. 32/2004, which was later taken over by the 2014 Local Government Law (Law Number 23 of 2014). Dian Agung Wicaksono, "Transformasi Pengaturan Distribusi Urusan Pemerintahan dari Pemerintah Pusat Kepada Pemerintahan Daerah", Padjadjaran Jurnal Ilmu Hukum, Vol. 2, No. 3, 2015, p. 476. 
of the Northern Ireland government, these types of functions are regulated flexibly, in contrast to the governance arrangements of Aceh that tend to be rigid.

This study depicts an important point that the issue of federalism in Indonesia is refuted in the case of the Aceh, in comparison with the UK in Northern Ireland experience. Moreover, the devolution of Northern Ireland that involves other countries, reinforces the perception that the federalism and the unitarism to some extent have similarity in certain degrees.

\section{References}

\section{Books}

Alder, John, General Principles of Constitutional and Administrative Law, Tenth Edition, Palgrave Macmillan, London, 2015.

Bagir Manan, Menyongsong Fajar Otonomi Daerah, Cetakan Ketiga, PSH FH UII, Yogyakarta, 2004.

Barendt, Eric, An Introduction To Constitutional Law, Oxford University Press, New York, 1998.

Barnett, Hilaire, Constitutional and Administrative Law, Fourth Edition, Cavendish Publishing Limited, London-Sydney, 2005.

Brown, Colin, A Short History Of Indonesia: The Unlikely Nation?, Allen \& Unwin, New South Wales, 2003.

Friend, Theodore, Indonesian Destinies, Harvard University Press, Massachusetts, 2003.

Ferry Mursyidan Baldan, Pondasi Menuju Perdamaian Abadi: Catatan Pembahasan RUU Pemerintahan Aceh, Suara Bebas, Jakarta, 2007.

Jowell, Jeffrey and Dawn Oliver (eds.), The Changing Constitution, Sixth Edition, Oxford University Press, New York, 2007.

Kohn, George Childs (ed.), Dictionary Of Wars, Third Edition, Facts On File Inc., New York, 2007.

Miller, Michelle Ann, Rebellion and Reform in Indonesia Jakarta's Security and Autonomy Policies in Aceh, Routledge, London-New York, 2009.

Ni'matul Huda, Desentralisasi Asimetris dalam NKRI Kajian Terhadap Daerah Istimewa, Daerah Khusus dan Otonomi Khusus, Nusamedia, Bandung, 2014.

Rabasa, Angel and Peter Chalk, Indonesia's Transformation and the stability of Southeast Asia, RAND, Santa Monica, 2001.

Smith, B.C., Decentralization the Territorial Dimension of the State, George Allen \& Unwin, London, 1985.

Smith, M.L.R., Fighting For Ireland? The Military Strategy of the Irish Republican Movement, Routledge, London, 1995.

Starke, J.G., Pengantar Hukum Internasional, Edisi Kesepuluh, translated by Bambang Iriana Djajaatmadja, Sinar Grafika, Jakarta, 2000. 
Strong, C.F. Modern Political Constitution, The English Language Book Society Sidgwick \& Jackson Limited, London, 1966.

Wilford, Rick, Robin Wilson (eds.), Northern Ireland Devolution Monitoring Report, The Constitution Unit - University College of London, London, 2006.

\section{Other Documents}

Aceh Feature, "Aceh: Federalisme atau Negara Kesatuan", Aceh Feature, http://www.acehfeature.org/index.php/site/detailartikel/301/Aceh,-

Federalisme-atau-Negara-Kesatuan/, accessed on April 2010.

Bayu Krisnapati, "Desentralisasi Asimetris Dalam Negara Kesatuan Republik Indonesia", Master's Thesis, Faculty of Law Universitas Islam Indonesia, 2012.

Bilal Dewansyah, Giri Ahmad Taufik, "Konsepsi Pemekaran Aceh (ALA, ABAS) dan Pengaruhnya Terhadap Peningkatan Kesejahteraan dan Kehidupan Kultural Masyarakat", paper presented in 7th International Seminar on Local Politics Dynamic , Lembaga Percik - Ford Foundation, Salatiga, July 17 - 19, 2007.

CFE OECD, "Asymmetric decentralisation: Policy implications in Colombia", 2019, http://www.oecd.org/countries/colombia/Asymmetric decentralisation Colom bia.pdf, accessed on June 2019.

Curtice, John, "A Stronger or Weaker Union? Public Reactions to Asymmetric Devolution in the UK", The Journal of Federalism, Vol. 36, No. 1, 2006.

Dian Agung Wicaksono, "Transformasi Pengaturan Distribusi Urusan Pemerintahan dari Pemerintah Pusat Kepada Pemerintahan Daerah", Padjadjaran Jurnal IImu Hukum (Journal of Law), Vol. 2, No. 3, 2015.

Doyle, John, "Towards a Lasting Peace?: the Northern Ireland multi-party agreement, referendum and Assembly elections of 1998", Scottish Affairs, 1998, http://ssrn.com/abstract=1297928, accessed on February 2010.

International IDEA \& Constitution Transformation Network, "Asymmetric Territorial Arrangements in Decentralized Systems", Constitutional INSIGHTS No. 3, October 2018, https://www.idea.int/sites/default/files/publications/asymmetric-territorialarrangements-in-decentralized-systems.pdf, accessed on January 2019.

International Crisis Group (ICG), "Aceh: Can Autonomy Stem The Conflict?", ICG Asia Report, No. 18, 2001.

Larsen, H.F., N. Selim, "Local Democracy and Peace Building in Asia: Devolution Arrangements and Power Sharing in Local Government Councils", background paper for Regional Technical Seminar on Local Governance and Basic Service Delivery in Conflict Affected Areas, Bangkok, 2-3 June 2009.

Leeke, Matthew, Chris Sear, and Oonagh Gay, "An Introduction To Devolution in The UK", Research Paper 03/84, 17 November, Parliament And Constitution Centre - House Of Commons Library, London, 2003, 
http://www.parliament.uk/commons/lib/research/rp2003/rp03-084.pdf, accessed on February 2019.

News BBC, "Northern Ireland chronology: 2002", http://news.bbc.co.uk/2/hi/uk news/northern ireland/2933949.stm, accessed on February 2019.

News BBC, "Northern Ireland chronology: 2003", http://news.bbc.co.uk/2/hi/uk news/northern ireland/2933951.stm, accessed on February 2019.

Pusat Studi Perdamaian dan Resolusi Konflik - Universitas Syiah Kuala, "Laporan Pemantauan Perdamaian Aceh", 2009, pp. 3-4., https://igrayman.files.wordpress.com/2010/05/laporan-pemantauanperdamaian-aceh-sep-dec2009.pdf, accessed on June 2019.

Smith, Connie, "Devolution in the UK: Powers and Structures in Scotland, Wales and Northern Ireland", Artikel Briefing No. 1, CliCP - The University of Edinburgh, Edinburgh, 2008, http://www.clicp.ed.ac.uk/publications/briefings/briefing01.pdf, accessed on February 2010.

Stange, Gunnar, Roman Patock, "From Rebels to Rulers and Legislators: The Political Transformation of the Free Aceh Movement (GAM) in Indonesia", Journal of Current Southeast Asian Affairs, Vol. 29, Issue 1, 2010.

Tempo Interaktif, "Irwandi: Tahu Teroris", http://www.tempointeraktif.com/hg/hukum/2010/03/09/brk.20100309231260.id.html, accessed on April 2010.

The Independent, "Why is there no government in Northern Ireland and how did power-sharing collapse?" https://www.independent.co.uk/news/uk/politics/northern-ireland-talkslatest-updates-stormont-power-sharing-deal-what-deal-look-sinn-fein-dupdeal-a8711691.html, accessed on February 2019.

\section{Legal Documents}

1945 Constitution of the Republic of Indonesia [Undang-Undang Dasar Negara Republik Indonesia Tahun 1945].

Law Number 22 of 1999 on Local Government. [Undang-Undang Nomor 22 Tahun 1999 Tentang Pemerintahan Daerah].

Law Number 18 of 2001 on Specialized Autonomy for Daerah Istimewa Aceh Province as Nangroe Aceh Darussalam Province [Undang-Undang Nomor 18 Tahun 2001 Tentang Otonomi Khusus bagi Provinsi Daerah Istimewa Aceh sebagai Provinsi Nangroe Aceh Darussalam].

Law Number 21 of 2001 on Specialized Autonomy for Papua Province. [UndangUndang Nomor 21 Tahun 2001 Tentang Otonomi Khusus bagi Provinsi Papua]. 
Law Number 32 of 2004 on Local Government. [Undang-Undang Nomor 32 Tahun 2004 Tentang Pemerintahan Daerah].

Law Number 11 of 2006 on the Government of Aceh [Undang-Undang Nomor 11 Tahun 2006 Tentang Pemerintahan Aceh].

Law Number 35 of 2008 on Penetapan Peraturan Pemerintah Pengganti UndangUndang Number 1 of 2008 on Revision of Law Number 21 of 2001 on Specialized Autonomy for Papua Province to be Law. [Undang-Undang Tentang Penetapan Peraturan Pemerintah Pengganti Nomor 1 Tahun 2008 tentang Perubahan Atas Undang- Undang Nomor 21 Tahun 2001 tentang Otonomi Khusus Bagi Provinsi Papua Menjadi Undang-Undang].

Law Number 23 of 2014 on Local Government. [Undang-Undang Nomor 23 Tahun 2014 Tentang Pemerintahan Daerah].

Government Regulation to Replace Law Number 1 of 2008 on Revision of Law Number 21 of 2001 on Specialized Autonomy for Papua Province. [Peraturan Pemerintah Pengganti Undang-Undang Nomor 1 Tahun 2018 Tentang Perubahan Undang- Undang Nomor 21 Tahun 2001 Tentang Otonomi Khusus Bagi Provinsi Papua].

Government Regulation Number 38 of 2007 on Allocation of Governmental Matters Between The Central Government, Provincial Governments, and District/Municipal Government [Peraturan Pemerintah Nomor 38 Tahun 2007 Tentang Pembagian Urusan Pemerintahan Antara Pemerintah, Pemerintahan Daerah Provinsi, dan Pemerintahan Daerah Kabupaten/Kota].

Memorandum of Understanding between the Government of the Republic of Indonesia and the Free Aceh Movement (MoU Helsinki) 2005, http://www.acehpeaceprocess.net/pdf/mou final.pdf.

NIA and Amendement,
https://www.legislation.gov.uk/ukpga/1998/47/contents. 